
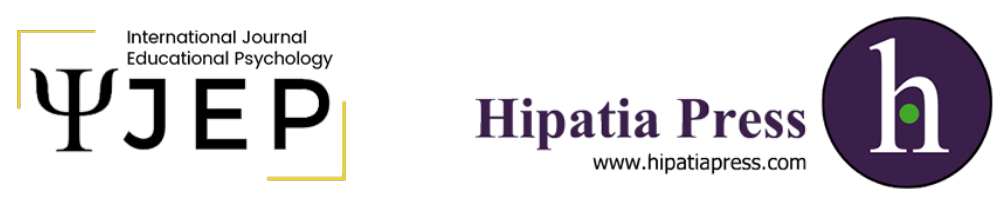

Instructions for authors, subscriptions and further details:

http://ijep.hipatiapress.com

\title{
List of 2020 Reviewers
}

Date of publication: February $24^{\text {th }}, 2021$

Edition period: February 2021 - June 2021

To cite this article: IJEP Editors (2021). List of Reviewers. International Journal of Educational Psychology, 10(1),108. doi: 10.17583/ijep.2021.7803

To link this article: http://dx.doi.org/10.17583/ijep.2021.7803

PLEASE SCROLL DOWN FOR ARTICLE

The terms and conditions of use are related to the Open Journal System and to Creative Commons Attribution License (CC-BY). 
IJEP - International Journal of Educational Psychology, Vol. 10 No. 1 February 2021 pp. 108

\section{List of 2020 Reviewers}

We thank the individuals who were reviewers for the International Journal of Educational Psychology over the year 2020. We deeply appreciate their contributions to the quality of the journal.

Rocío García-Carrión

Sandra Racionero-Plaza

Editors

Abdulkarim, Waleed

Antonelli-Ponti, Mayra

Barrentexea, Lucía

Bhatt, Aleshika

Diez Palomar, Javier

Duque Sánchez, Elena

Gairal, Regina

Khalfaoui, Andrea

Kuldas, Seffetullah

Lopez De Aguileta, Garazi

Loncaric, Darko

Martins, Mariana Ginja Da Costa

Merodio, Guiomar

Mishra, Hemanta Kumar

Mollina, Silvia

Morlà, Teresa

Bwaya, Christian Nathaniel

Rodríguez, Henar

2021 Hipatia Press

ISSN: 2014-3591

DOI: $10.17583 /$ ijep.2021.7803
Toledo, Ana

Yi-Ju Chen, Eva

Zengaro, Sally 